\title{
EFFECT OF SOME AROMATIC PLANTS BY PRODUCTS ON THE IN VITRO RUMEN FERMENTATION AND BUFFALO'S MILK PRODUCTION IN EARLY LACTATION
}

\author{
A.M. Abd El-Mola ${ }^{1}$, N.E. El-Bordeny ${ }^{2}$ and H.H. Azzaz ${ }^{3}$ and Hoda Al Zahar ${ }^{3}$ \\ ${ }^{1}$ Animal Production Department, Faculty of Agriculture, Fayoum University, Fayoum 63511, Egypt. \\ ${ }^{2}$ Animal Production Department, Faculty of Agriculture, Ain Shams University, Cairo, 11241, Egypt. \\ ${ }^{3}$ Dairy Sciences Department, National Research Centre, 33 Buhouth St., Dokki, Giza, 12311, Egypt.
}

(Received 26/9/2018, Accepted 15/11/2018)

\section{SUMMARY}

$\mathrm{E}$ valuate impact of the marjoram and parsley by-products on rumen fermentation characteristics (in vitro) and the productive performance of early lactating buffaloes (in vivo) are the main objectives of this study. Two in vitro experiments were conducted to evaluate the effect of partial and full substitution of control ration's rice straw by marjoram and parsley by-products on rumen fermentation characteristics. In the in vivo study; fifteen lactating buffaloes after 2 weeks of calving were randomly assigned into three groups using complete random design. Buffaloes were fed dry matter according to $3 \%$ of their body weight for 60 days. The first animal's group was fed on the control ration (60\% CFM and $40 \%$ rice straw). The second group was fed $60 \%$ CFM and $40 \%$ parsley by-products (CP100), while the third group was fed $60 \% \mathrm{CFM}$ and $40 \%$ marjoram by-products (CM100). The results indicated that full replacement of rice straw by marjoram (CM100) and parsley (CP100) by-products led to 1) significant (P < 0.05 ) increased in vitro degradability of ration's DM, OM, NDF and ADF with improving all ruminal basic parameters ( $\mathrm{pH}, \mathrm{NH} 3-\mathrm{N}$, TVFA, s, SCFA and total gas production. 2$)$ significant $(\mathrm{P}<0.05)$ increased in ability of the lactating buffaloes for more digestion of diet's DM, OM, CP and NFE. The buffaloes fed (CP100) ration had higher $(\mathrm{P}<0.05)$ blood plasma protein, albumin and globulin with higher $(\mathrm{P}<0.05) \mathrm{milk}, 4 \%$ fat corrected milk (FCM) and all milk component yields. It could be concluded that; parsley by-products significantly enhance buffalo's milk production with no harmful effects on their health and we recommend them as roughage sources, especially in the summer.

Keywords: Aromatic plants by-products, marjoram, parsley, in vitro, buffaloes, milk yield and milk composition.

\section{INTRODUCTION}

Aromatic plants gotten more interest by scientific researchers as well as industry men because of their strong antimicrobial and antioxidant properties and significant nutritional content of minerals, phenols and carotenoids (Ozcan et al., 2005; Suhaj, 2006 and Azzaz et al., 2016). Today the aromatic plants are cultivated in several areas of Egypt especially in villages of Fayoum and Beni Sueif provinces. The total cultivated area with medicinal and aromatic plants in Egypt reached 63347 feddans and produce around 100690 ton/year (Agricultural Economics, 2007).

Sweet marjoram (Origanum majorana L) and parsley (Petroselinium crispum) are widely used as a garnish and are used for different medicinal purposes in folklore medicine of Egypt. Sweet marjoram is aromatic herb grows to a height of 30 to $60 \mathrm{~cm}$ with large number of leafy stalks with small leaves and white or red small flowers. The most of marjoram essential oil is found in the leaves, whereas only traces are found in flowers and stalks (Potty and Krishna Kumar, 2001). On the other hand, parsley grows from one root and their heights about 60 to $100 \mathrm{~cm}$, the leaves (main part) are tripinnate and possesses the essential oil (Farzaei et al., 2013). Both of these plants are harvested in early summer before flowering 
and the foliage is cut off about $6 \mathrm{~cm}$ above the ground and it will put out new shoots and yield another crop in autumn (Potty and Krishna Kumar, 2001).

For industrial purpose, the marjoram and parsley leaves are dried, carefully cleaned and stored. Stems or stalks (by-products) are separated from leaves by rubbing on hand sieves of 1 to $2 \mathrm{~cm}$ mesh. These byproducts can serve as roughages for farm animal feeding, especially that prices of wheat and rice straws (main roughages used in animal feeding in summer) are continuously elevating. The attempts to use aromatic plants by-products as feed resources for calves, cows and sheep have been reported (Wojcik et al., 1984, Tiwari et al., 1996 and Djouvinov et al., 1997). In this concern, some of agricultural byproducts have been fully screened for their uses in animal feeding such as wheat straw and rice straw. Whilst many more are yet to be evaluated before being used as animal feed, aromatic plants by-products are among of them. Therefore, this study was conducted to evaluate impact of the marjoram and parsley by-products on rumen fermentation characteristics (in vitro) and the productive performance of early lactating buffaloes (in vivo).

\section{MATERIALS AND METHODS}

The in vitro studies and the chemical analysis were carried out at the laboratories of Diary Department, National Research Center, Dokki, Giza, Egypt and Animal Production Department, Faculty of Agriculture, Ain Shams University, Egypt. The in vivo part of this work was carried out at the experimental station of Animal Production Department, Faculty of Agriculture, Fayoum University, Egypt.

\section{In vitro studies:}

Two in vitro experiments were conducted for investigate the potential use of marjoram and parsley by-products as ruminant feed ingredient. In the first one, ruminal "in vitro" dry matter and organic matter digestion (IVDMD \& IVOMD) for marjoram and parsley by-products as a replacement for rice straw of the control ration at different percentages, 25,50,75 and $100 \%$ have been determined. The control ration consisted of $60 \%$ concentrate feed mixture (52\% yellow corn, $20 \%$ soybean cake, $10 \%$ wheat bran, $10 \%$ rice bran, $3.5 \%$ molasses, $3 \%$ limestone, $1 \%$ common salt and $0.5 \%$ minerals mixture) and $40 \%$ rice straw. The chemical composition of feed ingredients is shown in Table (1), while the chemical composition of the tested rations is shown in Table (2). For obtaining of the rumen microorganisms (inoculum), rumen fluid was collected from rumen of slaughtered rams fed berseem hay ration. The obtained liquor was squeezed through four layered cheesecloth into a warmed oxygen-free plastic jars and immediately transported to laboratory at $39^{\circ} \mathrm{C}$. Approximately $400 \mathrm{mg}$ of each tested ration (ground through a $2 \mathrm{~mm}$ screen) was accurately weighed separately into $125-\mathrm{ml}$ bottles. Each ration was tested in 6 replicates accompanied by 6 blank bottles (no substrate). Each bottle was filled with $40 \mathrm{ml}$ of mixture of 1:3 (v/v) rumen fluids: buffer solution as described by Tilley and Terry (1963).

Table (1): Chemical composition of feed ingredients (on DM basis).

\begin{tabular}{lccccccccc}
\hline Item & DM & OM & CP & EE & CF & NDF & ADF & NFE & Ash \\
\hline CFM & 91.90 & 91.40 & 15.40 & 3.40 & 15.10 & 22.90 & 16.36 & 57.5 & 8.60 \\
Rice straw & 92.76 & 88.09 & 2.95 & 1.53 & 39.81 & 72.00 & 47.00 & 43.8 & 11.91 \\
Parsley by-products & 92.01 & 79.85 & 10.24 & 2.52 & 26.09 & 29.92 & 21.20 & 41.0 & 20.15 \\
Majoram by-products & 93.10 & 81.43 & 9.12 & 2.75 & 29.26 & 63.72 & 53.32 & 40.3 & 18.57 \\
\hline
\end{tabular}

CFM: Concentrate feed mixture, DM: Dry matter, OM: Organic matter, CP: Crude protein, EE: Ether extract, NFE: Nitrogen free extract, NDF: Neutral detergent fiber, ADF: Acid detergent fiber and CF: Crude fiber

Concentrate feed mixture composed of $52 \%$ yellow corn, $20 \%$ soybean cake, $10 \%$ wheat bran, $10 \%$ rice bran, $3.5 \%$ molasses, $3 \%$ limestone, $1 \%$ common salt and $0.5 \%$ minerals mixture 
In the second in vitro study; batch fermentation culture experiment was conducted according to ElSherbiny et al. (2016) to evaluate the effect of full substitution of control ration's rice straw by marjoram and parsley by-products on rumen fermentation characteristics. Each treatment was tested in 3 replicates accompanied by 3 blank vessels (no substrate). The tested rations $(400 \mathrm{mg}$ ) were added separately to the $125 \mathrm{ml}$ incubation vessels. Each vessel was filled with $40 \mathrm{ml}$ of mixture of 1:3 (v/v) rumen fluids: buffer solution. All vessels were sealed and incubated at $39^{\circ} \mathrm{C}$ for $24 \mathrm{~h}$. After $24 \mathrm{~h}$ of incubation, all vessels were filtered in fiber filter bags 25 micron porosity (ANKOM- USA). The residues in the bags were dried at $70^{\circ} \mathrm{C}$ in oven for $48 \mathrm{~h}$ to analyses dry matter (DM), organic matter (OM), neutral detergent fiber (NDF) and acid detergent fiber (ADF) digestibility. The NDF and ADF were determined using the methods described by Van Soest et al., (1991). Rumen fluid $\mathrm{pH}$ was measured using (pH-meter). Overall volume of the produced gases was determined using Hohenheim Syringes $(100 \mathrm{ml})$ as described by Navarro-Villa et al., (2011). Quantitative analysis of ammonia concentration was carried out by a modified Nessler's method as described by Szczechowiak et al. (2016). The total volatile fatty acids (VFA) were determined by steam distillation method as described by Warner (1964). The short chain fatty acids (SCFA) concentration was calculated according to equation of Makkar (2005) as the following equation:

$$
\text { SCFA }(\mathrm{mmol})=0.0222 \mathrm{Gas}-0.00425
$$

Where, Gas: is gas production at 24 hours incubation ( $\mathrm{ml} / 200 \mathrm{mg} \mathrm{DM})$

Table (2): Chemical composition and in vitro degradability of the tested rations (on DM basis).

\begin{tabular}{|c|c|c|c|c|c|c|c|c|c|c|}
\hline Item & Control & CP25 & CP50 & CP75 & CP100 & CM25 & CM50 & CM75 & CM100 & $\mathrm{SE}^{ \pm}$ \\
\hline DM & 92.24 & 92.17 & .09 & 92.02 & 91.94 & 92.28 & 92.31 & .35 & 2.38 & 0.03 \\
\hline & & 25 & & 60 & 5.78 & 1 & 4 & 08 & & .21 \\
\hline & & & & & & & & & & \\
\hline E & 2.65 & 2.75 & 5 & 95 & 3.05 & 2.77 & 2.90 & .02 & & .03 \\
\hline $\mathrm{CF}$ & 24 & 61 & 2.24 & 37 & & 3 & 7 & 2 & 6 & .48 \\
\hline $\mathrm{FE}$ & & & & & & & & & & \\
\hline DF & 4 & 33 & .12 & 92 & & 41.71 & 40.88 & 40.66 & 23 & .32 \\
\hline & & & & 4 & & & & & & 05 \\
\hline & & 15 & & 2.40 & & & & & & 0.20 \\
\hline & 39.1 & $41.57^{\mathrm{b}}$ & $42.41^{\mathrm{b}}$ & $47.69^{\mathrm{ab}}$ & $53.33^{\mathrm{a}}$ & $40.09^{\mathrm{b}}$ & $41.98^{\mathrm{b}}$ & $43.68^{\mathrm{b}}$ & $47.22^{\mathrm{ab}}$ & 1.29 \\
\hline IVOMD\% & $43.60^{\mathrm{b}}$ & $46.00^{\mathrm{b}}$ & $46.84^{\mathrm{b}}$ & $52.12^{\mathrm{ab}}$ & $57.76^{\mathrm{a}}$ & $44.52^{\mathrm{b}}$ & $46.41^{\mathrm{b}}$ & $48.11^{\mathrm{b}}$ & $55.18^{\mathrm{a}}$ & 1.30 \\
\hline \multicolumn{11}{|c|}{$\begin{array}{l}\text { Control: } 60 \% \text { CFM+40\% Rice straw, CP25: } 60 \% \text { CFM+30\% Rice straw+10\% Parsley by-product, CP50:60\% } \\
\text { CFM+20\% Rice straw+20\% Parsley by-product, CP75:60\% CFM+10\% Rice straw+30\% Parsley by-product, } \\
\text { CP100:60\% CFM+40\% Parsley by-product, CM25: 60\% CFM+30\% Rice straw+10\% Majoram by-product, CM50: } \\
\text { 60\% CFM+20\% Rice straw+20\% Majoram by- product, CM75: } 60 \% \text { CFM+10\% Rice straw+30\% Majoram by- } \\
\text { product, CM100: } 60 \% \text { CFM+ } 40 \% \text { Majoram by- product, IVDMD } \%: \text { in vitro dry matter degradability and } \\
\text { IVOMD\%: in vitro organic matter degradability. } \\
\text { a and b means at the same row with different superscript are significantly }(P<0.05) \text { different. } \\
\pm \text { ISE: standard error }\end{array}$} \\
\hline
\end{tabular}

\section{In vivo study:}

\section{Digestibility and lactation trails:}

Fifteen lactating buffaloes (aged 4-6 years and weighting $550 \mathrm{~kg}$ on average), after 2 weeks of calving were randomly assigned into three groups, 5 animals each, using complete random design. The entire experimental period was 60 days. Buffaloes were fed dry matter according to $3 \%$ of their body weight. The first animal's group was fed on the control ration (that is consisted of 60\% CFM and $40 \%$ rice straw). The second group was fed $60 \%$ CFM and $40 \%$ parsley by-products (CP100), while the third group was fed $60 \%$ CFM and $40 \%$ marjoram by-products (CM100). The rations were offered twice daily at 8.00 a.m. and 4:00 pm and the fresh water was available all the time for all experimental groups. The chemical composition of the tested rations is shown in Table (2).

During the final three days of each month of the experimental period (60 days), feces were collected from the rectum of each animal by hand at 12:00 p.m., dried at $60{ }^{\circ} \mathrm{C}$ for $48 \mathrm{~h}$, and then ground for chemical analysis. Acid insoluble ash technique of Ferret et al, (1999) was used for determination of 
nutrient digestion coefficients. The nutrients digestibility coefficients were calculated according to the following formula:

$$
\text { Digestion co-efficient }=\quad 100-\left[100 \times \frac{\% \text { indicator in feed }}{\% \text { indicator in feces }} \times \frac{\% \text { nutrient in feces }}{\% \text { nutrient in feed }}\right]
$$

\section{Feed and fecal analysis:}

Chemical analysis of feed stuffs and feces samples were carried out to determine the percentage of dry matter (DM), crude protein (CP), ether extract (EE), crude fiber (CF) and ash content using the methods of A.O.A.C. (1995). The nitrogen free extract (NFE) was calculated by difference [100- (CP+ EE+ CF+ ash)].

\section{Sampling and analysis of blood plasma:}

At the last day of each month of the experimental period, blood samples were collected in glass tubes containing EDTA as an anticoagulant agent from the jugular vein of each animal at 12:00 p.m. (4h after the distribution of morning feed) and then centrifuged at 4000 r.p.m. $/ 20$ min. to separate the plasma. The obtained plasma was stored at $-18{ }^{\circ} \mathrm{C}$ till analysis. Plasma total protein and albumin were determined as described by Armstrong and Carr (1964) and Doumas et al. (1971), respectively. Then globulin and albumin/globulin ratio were calculated. Plasma creatinine concentration was determined according to method of Henary (1974), while cholesterol and triglycerides was determined according to method of Burtis et al. (2006).

\section{Sampling and analysis of milk:}

Milk samples were taken every 2 weeks throughout the experimental period. Buffaloes were milked by hand twice a day at 8:00 am and 7:00 pm. Milk samples were collected immediately from each animal after morning and evening milking and milk yield was recorded. Milk samples were analyzed for total solids, fat, total protein and lactose by Bentley ${ }^{150}$ infrared milk analyzer (Bentley Instruments, Chaska, MN, USA) according to A.O.A.C. (1995) procedures. Solids-not-fat (SNF) was calculated. Fat corrected milk (4\% fat) was calculated by using the following equation according to Gaines, (1928):

$\mathrm{FCM}=0.4 \mathrm{M}+15 \mathrm{~F}$, Where: $\mathrm{FCM}=$ fat-corrected milk, $\mathrm{M}=$ milk yield $(\mathrm{g})$ and $\mathrm{F}=$ fat yield $(\mathrm{g})$.

\section{Statistical analysis:}

Data obtained from this study were statistically analyzed by SPSS (2008) according to the following model:

$$
\mathrm{Y}_{\mathrm{ij}}=\mu+\mathrm{T}_{\mathrm{i}}+\mathrm{e}_{\mathrm{ij}}
$$

Where $\mathrm{Y}_{\mathrm{ij}}$ is the parameter under analysis of the ij in vitro bottle or buffalo, $\mu$ is the overall mean, $\mathrm{T}_{\mathrm{i}}$ is the effect due to treatment on the parameter under analysis, eij is the experimental error for $\mathrm{ij}$ on the observation. Duncan's multiple range tests were used to test the significance among means (Duncan, 1955).

\section{RESULTS AND DISCUSSION}

\section{In vitro studies:}

Data of Table (2) showed gradual increase in the in vitro dry matter (IVDMD \%) and organic matter (IVOMD \%) degradability with increasing level of marjoram and parsley by-products inclusion in the rations. Increasing level of marjoram and parsley by-products inclusion up to $100 \%$ gave the highest $(\mathrm{P}<0.05)$ values of IVDMD \% and IVOMD \%. This may be due to increase in microbial colonization of feed particles due to higher CP and EE with lower CF, NDF and ADF contents of marjoram and parsley by-products than those of rice straw (Table, 1). The results of the in vitro batch culture match the data of 
the first in vitro trial (Table, 3). The full replacement of rice straw by marjoram (CM100) and parsley (CP100) by-products led to significant $(\mathrm{P}<0.05)$ increase in degradability $(\%)$ of ration's DM, OM, NDF and ADF with improve all ruminal basic parameters (e.g. $\mathrm{pH}, \mathrm{NH}_{3}$-N,TVFA,SCFA and total gas production (Table, 3). It is worth to mention that, parsley by-products inclusion in the rations showed superiority over marjoram by-products for improving IVDMD \% and IVOMD \% (first in vitro trial) and all rumen characteristics (second in vitro trial). The lowest $\mathrm{pH}$ value was recorded by $\mathrm{CP} 100$ followed by CM100, while the highest $\mathrm{pH}$ value was recorded by the control ration. In contrast, ammonia-nitrogen $\left(\mathrm{NH}_{3}-\mathrm{N}\right)$, total volatile fatty acids (TVFA), and short chain fatty acids (SCFA) concentrations and total gas production volume recorded the highest values by CP100 followed by CM100, while the lowest values were recorded by the control ration (Table 3). The pattern of $\mathrm{pH}$, TVFA's and $\mathrm{NH}_{3}-\mathrm{N}$ concentrations and volume of total gas production reflects the pattern of fermentation efficiency in the rumen. The superiority of parsley by-products over marjoram by-products and rice straw is reasonable due to its higher $\mathrm{CP}$ and $\mathrm{EE}$ with lower $\mathrm{CF}, \mathrm{NDF}$ and $\mathrm{ADF}$ contents, which led to increase digestion and metabolism activity of the rumen microflora and enhance liberation of a large amount of fermentable carbohydrate and ammonia-nitrogen which in turn causes higher TVFA, SCFA and total gases production (Azzaz et al., 2016) On the other hand, the antioxidant and antimicrobial activities of parsley and marjoram by-products may provide a suitable environment for the growth of beneficial microflora in the rumen and let for more feed nutrients fermentation and subsequently more $\mathrm{NH}_{3}-\mathrm{N}$ and TVFA's production (Azzaz et al., 2016).

Table (3): Effect of tested rations on invitro rumen characteristics.

\begin{tabular}{|c|c|c|c|c|}
\hline Item & Control & CP100 & CM100 & $\mathrm{SE} \pm$ \\
\hline \multicolumn{5}{|l|}{ Degradability $\%$} \\
\hline Dry matter & $55.03^{\mathrm{c}}$ & $69.00^{\mathrm{a}}$ & $65.41^{\mathrm{b}}$ & 2.13 \\
\hline Organic matter & $64.93^{\mathrm{c}}$ & $82.21^{\mathrm{a}}$ & $78.00^{\mathrm{b}}$ & 2.63 \\
\hline Neutral detergent fiber & $43.59^{c}$ & $61.61^{\mathrm{a}}$ & $54.57^{\mathrm{b}}$ & 2.64 \\
\hline Acid detergent fiber & $26.30^{\mathrm{b}}$ & $52.56^{\mathrm{a}}$ & $33.77^{\mathrm{b}}$ & 4.14 \\
\hline \multicolumn{5}{|l|}{ Rumen basic parameters } \\
\hline $\mathrm{pH}$ & $6.64^{\mathrm{a}}$ & $6.57^{\mathrm{b}}$ & $6.60^{\mathrm{ab}}$ & 0.01 \\
\hline Ammonia-Nitrogen $(\mu \mathrm{mol} / \mathrm{L})$ & $0.60^{\mathrm{c}}$ & $1.08^{\mathrm{a}}$ & $0.83^{\mathrm{b}}$ & 0.14 \\
\hline Total volatile fatty acids (mEq/dl) & $6.90^{\mathrm{b}}$ & $8.00^{\mathrm{a}}$ & $7.77^{\mathrm{ab}}$ & 0.22 \\
\hline Short chain fatty acids $(\mathrm{mEq} / \mathrm{dl})$ & $1.68^{c}$ & $1.77^{\mathrm{a}}$ & $1.71^{\mathrm{b}}$ & 0.01 \\
\hline Total gas production $(\mathrm{ml} / 24 \mathrm{hr})$ & $137.67^{\mathrm{c}}$ & $144.67^{\mathrm{a}}$ & $140.33^{b}$ & 1.03 \\
\hline
\end{tabular}

\section{In vivo study:}

\section{Nutrients digestibility and nutritive value:}

Data of Table (4) showed significant $(\mathrm{P}<0.05)$ higher of apparent digestibility of DM, OM, CP and NFE for buffaloes fed parsley and marjoram by-products containing ration (CP100 and CM100) compared with those fed the control ration, while EE and CF digestibility were not changed among all groups. The nutritive values of the experimental rations as total digestible nutrients (TDN) and digestible crude protein (DCP) are shown in Table (4). The buffaloes fed (CP100) showed the highest $(\mathrm{P}<0.05)$ TDN and DCP values, followed by buffaloes fed (CM100) then buffaloes fed the control ration, which recorded lowest values for TDN and DCP. These results are in line with those obtained by Wojcik et al., (1984), Allam et al., (1999) and Mohamed and Ibrahem (2003). The improvement in nutrients digestibility and nutritive values of rations contain aromatic plants by products (CP100 and CM100) may be due to increase digestion and metabolism activity of the rumen microflora as direct effect of effective substances (phenols and carotenoids) of marjoram and parsley by-products (Farzaei et al., 2013). Also, the strong antimicrobial and antioxidant properties of parsley and marjoram by-products may play an important role in growth inhibition of the ruminal methanogenic bacteria (archaea) and thereby increase digestion efficiency and decrease losses of ration energy for more milk production. 
Table (4): Effect of tested rations on digestibility coefficients and nutritive values.

\begin{tabular}{lcccc}
\hline Item & Control & CP100 & CM100 & \pm SE \\
\hline Apparent nutrients digestibility $(\%)$ & & & \\
Dry matter & $60.89^{\mathrm{b}}$ & $65.09^{\mathrm{a}}$ & $63.64^{\mathrm{a}}$ & 0.69 \\
Organic matter & $64.41^{\mathrm{b}}$ & $68.02^{\mathrm{a}}$ & $65.58^{\mathrm{a}}$ & 0.66 \\
Crude protein & $57.61^{\mathrm{c}}$ & $78.03^{\mathrm{a}}$ & $68.39^{\mathrm{b}}$ & 3.13 \\
Ether extract & 74.76 & 80.78 & 81.29 & 1.67 \\
Crude fiber & 59.28 & 61.76 & 59.68 & 0.78 \\
Nitrogen free extract & $71.16^{\mathrm{b}}$ & $75.62^{\mathrm{a}}$ & $74.65^{\mathrm{a}}$ & 0.90 \\
Nutritive value $(\%):$ & & & & \\
TDN & $62.31^{\mathrm{b}}$ & $66.48^{\mathrm{a}}$ & $64.74^{\mathrm{ab}}$ & 0.78 \\
DCP & $6.00^{\mathrm{c}}$ & $10.41^{\mathrm{a}}$ & $8.81^{\mathrm{b}}$ & 0.66 \\
\hline
\end{tabular}

TDN: Total digestible nutrients, DCP: Digestible crude protein, Control: $60 \%$ CFM+40\% Rice straw, CP100:60\% CFM+40\% Parsley by-product and CM100: 60\% CFM+ 40\% Majoram by-product $a, b$ and $c$ means at the same row with different superscript are significantly $(P<0.05)$ different. \pm SE: standard error

\section{Blood parameters:}

The buffaloes fed $(\mathrm{CP} 100)$ ration had higher $(\mathrm{P}<0.05)$ plasma protein, albumin and globulin values followed by those fed (CM100), while buffaloes fed control ration recorded the lowest plasma protein, albumin and globulin values (Table 5). This may be due to a higher crude protein (CP) content of parsley by-products (Table 1) beside higher crude protein (CP) digestibility by buffaloes fed (CP100) ration compared to other animal's groups (Table 4). In contrast, the buffaloes fed control ration had higher $(\mathrm{p}<0.05)$ plasma creatinine and cholesterol than those fed rations containing aromatic plants by products (CP100 and CM100). This reflects the positive effect of parsley and marjoram by-products on the metabolic process as well as animal's health. In addition, there were no significant differences between all animal's groups in plasma albumin / globulin ratio and triglycerides concentrations. It is worth mentioning that all measured blood plasma parameters among the experimental buffaloe's groups are within the normal physiological range for healthy animals.

Table (5): Effect of tested rations on blood parameters of lactating buffaloes.

\begin{tabular}{lcccc}
\hline Item & Control & CP100 & CM100 & \pm SE \\
\hline Total protein (g/dl) & $5.87^{\mathrm{c}}$ & $6.81^{\mathrm{a}}$ & $6.52^{\mathrm{b}}$ & 0.14 \\
Albumin (g/dl) & $2.84^{\mathrm{b}}$ & $3.34^{\mathrm{a}}$ & $3.45^{\mathrm{a}}$ & 0.12 \\
Globulin (g/dl) & $3.03^{\mathrm{b}}$ & $3.47^{\mathrm{a}}$ & $3.07^{\mathrm{b}}$ & 0.10 \\
A/G ratio & 0.94 & 1.11 & 0.93 & 0.05 \\
Cereatinine (mg/dl) & $1.25^{\mathrm{a}}$ & $1.02^{\mathrm{b}}$ & $1.13^{\mathrm{ab}}$ & 0.04 \\
Cholesterol (mg/dl) & $98.47^{\mathrm{a}}$ & $95.71^{\mathrm{b}}$ & $91.79^{\mathrm{b}}$ & 1.07 \\
Triglycerides (mg/dl) & 49.25 & 50.84 & 50.88 & 0.24 \\
\hline
\end{tabular}

A/G: Albumin/ Globulin ratio.

$a, b$ and $c$ means at the same row with different superscript are significantly $(P<0.05)$ different. $\pm S E$ : standard error

\section{Milk yield and composition:}

Milk composition was not affected by inclusion of aromatic plants byproducts in buffaloe's rations, while milk and $4 \%$ fat corrected milk $(F C M)$ and all milk component yields were higher $(p<0.05)$ for buffaloes fed (CP100) ration than those fed the control and CM100 rations (Table 6). Inclusion of parsley by-products in lactating buffaloe's rations increased their milk production by $14.81 \%$ and fat corrected milk production by $17.4 \%$, while inclusion of marjoram by-products increased buffaloe's milk production by just $3.3 \%$ and fat corrected milk production by $3.2 \%$ compared with the control. These findings are in agreement with the results obtained by El-Garhy $(2012 a, b)$. This response may be attributed to generation of more nutrients which become available as a result of improvements in feed digestibility 
(Table 4). In addition, increase ruminally fermented DM and OM (Table 2, 3) may result in a numerical downward shift in the ratio of acetate to propionate, which may lead to increase delivery of glucogenic precursors to the mammary gland.

Table (6): Effect of tested rations on buffalo's milk yield and composition.

\begin{tabular}{lllll}
\hline Item & Control & CP100 & CM100 & \pm SE \\
\hline Milk yield & & & & \\
Milk yield (Kg/d) & $7.02^{\mathrm{b}}$ & $8.06^{\mathrm{a}}$ & $7.25^{\mathrm{b}}$ & 0.09 \\
$4 \%$ FCM yield (Kg/d) & $9.15^{\mathrm{b}}$ & $10.74^{\mathrm{a}}$ & $9.44^{\mathrm{b}}$ & 0.15 \\
Protein yield (g/d) & $191.39^{\mathrm{b}}$ & $225.23^{\mathrm{a}}$ & $198.92^{\mathrm{b}}$ & 4.88 \\
Fat yield (g/d) & $423.07^{\mathrm{b}}$ & $501.23 \mathrm{a}$ & $439.57^{\mathrm{b}}$ & 8.32 \\
Lactose yield (g/d) & $381.59^{\mathrm{b}}$ & $482.98^{\mathrm{a}}$ & $435.06^{\mathrm{ab}}$ & 13.48 \\
Ash yield (g/d) & $49.01^{\mathrm{b}}$ & $55.65^{\mathrm{a}}$ & $51.16^{\mathrm{ab}}$ & 1.05 \\
Total solids yield (g/d) & $1043.57^{\mathrm{b}}$ & $1245.7^{\mathrm{a}}$ & $1095.75^{\mathrm{b}}$ & 20.35 \\
Solids not fat yield (g/d) & $620.51^{\mathrm{b}}$ & $744.47^{\mathrm{a}}$ & $662.8^{\mathrm{b}}$ & 14.68 \\
Milk composition \% & & & & \\
Total protein & 2.71 & 2.79 & 2.74 & 0.05 \\
Fat & 6.03 & 6.21 & 6.06 & 0.07 \\
Lactose & 5.48 & 6.03 & 6.00 & 0.17 \\
Ash & 0.70 & 0.69 & 0.71 & 0.01 \\
Total solids & 14.89 & 15.49 & 15.11 & 0.20 \\
Solids not fat & 8.86 & 9.28 & 9.13 & 0.16 \\
\hline
\end{tabular}

$a$ and $b$ means at the same row with different superscript are significantly $(P<0.05)$ different.

$\pm S E$ : standard error.

\section{CONCLUSION}

It can be concluded that inclusion of parsley and marjoram by-products up to $40 \%$ in lactating buffaloes rations positively affect rumen fermentation characteristics (in vitro) and improve nutrient digestibility (in vivo). Parsley by-products significantly enhance buffalo's milk production and it is recommend as roughage source especially in the summer.

\section{REFERENCES}

AOAC (1995). Official Methods of Analysis of AOAC International, Agricultural, Chemicals, Contaminants, Drugs. $16^{\text {th }}$ Ed., Washington DC USA.

Agricultural Economics (2007). Central administration, Agricultural Economics. An economic study for production and exports of some medical and aromatically plants. Economics Affairs sector, Ministry of Agric., ARE.

Allam S.M, H.M. El-Hossieny, A.M. Abdel-Gawad, S.A. El-Saadany and A.M.M. Zeid (1999). Medicinal herbs and plants as feed additives for ruminants. 1-Effect of using some medicinal herbs and plants as feeds additives on Zaraibi goat performance. Egyptian J. Nutrition and Feeds. 2 (special issue): 349 .

Armstrong, W.D. and. C.W. Carr (1964). Physiological Chemistry, $3^{\text {re }}$ ed. Minneapolis Minnesota USA: Laboratory Directions Bures Publishing Co.

Azzaz, H.H., Eman S.A. Farahat, T.A. Morsy, Hend A. Aziz, Fatma I. Hadhoud and M.S. Abd-Alla (2016). Moringaoleifera and Echinacea purpurea as supplements for Rhamani lactating ewe's diets and their effect on rumen characteristics, nutrients digestibility, blood parameters, milk production, composition and its fatty acid profile. Asian J. Anim. Vet. Adv., 11: 684-692.

Burtis, C.A., E.R. Ashwood and D.E. Bruns (2006). Tietz Textbook of Clinical Chemistry and Molecular Diagnostics. $4^{\text {th }}$ Ed, Elsevier Saunders, 942-956. 
Djouvinov, D., D. Pavlov, A. Ilchev and E. Enev (1997). Peppermint (Mentha piperita Huds.) and basil (Ocimum basilicum L.) etheric oil by-products as roughages for sheep feeding. Animal Feed Science and Technology, 68(3-4): 287-294. Doi: 10.1016/s0377-8401(97) 00048-5.

Doumas, B., W. Wabson and H. Biggs (1971). Albumin standards and measurement of serum with bromocresol green. Clinica Chimica Acta., 31: 87.

Duncan, D.B. (1955). Multiple range and multiple F tests. Biometrics. 11: 1.

El-Garhy, G.M. (2012a). Effect of feeding Chamomile by products (Matricaria Chamomilla) on performance of lactating buffaloes. Egyptian J. Nutrition and Feeds, 15(2): 217-222.

El-Garhy, G.M. (2012b). Effect of feeding Anise by products on performance of lactating buffaloes. Egyptian J. Nutrition and Feeds, 15(2): 223-228.

El-Sherbiny, M., A. Cieslak, E. Pers-Kamczyc, J. Szczechowiak, D. Kowalczyk and M. SzumacherStrabel (2016). A nanoemulsified form of oil blends positively affects the fatty acid proportion in ruminal batch cultures. J. Dairy Sci., 99: 399-407.

Farzaei, M.H, Abbasabadi, Z, Ardekani, M.R.S, Rahimi, R, and Fatemeh Farzaei (2013). Parsley: a review of ethnopharmacology, phytochemistry and biological activities. J. Tradit Chin Med. 33(6): 815-826.

Ferret, A, J. Plaixats, G. Caja, J. Gasa and. P. Prió (1999). Using markers to estimate apparent dry matter digestibility, faecal output and dry matter intake in dairy ewes fed Italian ryegrass hay or alfalfa hay. Small Ruminant Research. 33: 145-152.

Gaines, W. L. (1928). The energy basis of measuring energy milk in dairy cows. Univ Illinois Agric.

Henary, R. J. (1974). Clinical Chemistry, Principles and Techniques. Second Edition, Harper and row, p 525.

Makkar, H.P., (2005). In vitro gas methods for evaluation of feeds containing phytochemicals. Anim. Feed Sci. Technol., 123: 291-302.

Mohamed, A.H and and K. Ibrahem (2003). Incorporation aromatic plants by products in ruminant diet 1Effect of using aromatic plants by products on growing lambs performance. Egyptian J. Nutrition and Feeds. 6 (special issue): 1209

Navarro-Villa, A., M. O’brien, S. López, T.M. Boland and P. O’kiely (2011). Modifications of a gas production technique for assessing in vitro rumen methane production from feedstuffs. Anim. Feed Sci. Technol., 166: 163-174.

Ozcan, M., D. Arslan and A. Unver (2005). Effect of drying methods on the mineral content of basil (Ocimum basilicum L.). Journal of Food Engineering, 69, pp.375- 379

Potty, S. N. and V. Krishna Kumar (2001). Marjoram in: Handbook of herbs and spices. Peter, K. V Wood head publishing Limited, Cambridge CB1 6AH, England. Pages 216-237.

SPSS (2008). Statistical package for Social Sciences, Statistics for Windows, Version 17.0. Released 2008. Chicago, U.S.A.: SPSS Inc.

Suhaj, M. (2006). Spice antioxidants isolation and their antiradical activity: a review. Journal of Food Composition and Analysis, 19, pp. 531- 537.

Szczechowiak, J., M. Szumacher-Strabel, M. El-Sherbiny, E. Pers-Kamczyc, P. Pawlakand and A. Cieslak (2016). Rumen fermentation, methane concentration and fatty acid proportion in the rumen and milk of dairy cows fed condensed tannin and/or fish-soybean oils blend. Anim. Feed Sci. Technol. 216: 93-107.

Tilley, J.M. and R.A. Terry (1963). A two stage technique for the in vitro digestion of forage crops. J. Brit. Grass Soc., 18: 104-111.

Tiwari, D.P., C.M. Tiwari, R.K. Jain, C.P. Mishra and U.K. Mishra (1996). Nutritive evaluation of Vantulsa (Oscimum bascilimum) by-product in Sahiwal cows. Indian J. of Anim Nutr.13:178.

Van Soest, P.J., J.B. Robertson and B.A. Lewis (1991). Methods for dietary fiber, neutral detergent fiber and non-starch polysaccharides in relation to animal nutrition. Journal of Dairy Science. 74: 35833597.

Warner, A.C., (1964). Production of volatile fatty acids in the rumen: Methods of Measurements. Nutr. Abst. Rev., 34: 339-352.

Wojcik, S., S. Blaziak, K. Widensk and K. Zawislak (1984). Feeding value of some herbal by-products. Biuletyninformacyjnyprzemyshepaszowego. 23:29. 
تأثير مخلفات بعض النباتات العطرية على تخمرات الكرش معمليا وعلى انتاج اللبن من الجاموس الحلاب فى مرحلة الحليب المبكر العزات

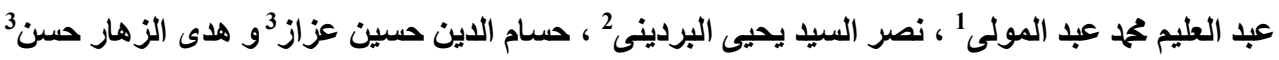 \\ 1 قسم الاتتاج الحيوانى ـ كلية الزراعة - جامعة الفيوم - الفيوم - مصر.

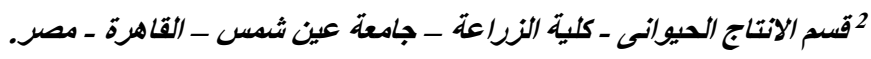 \\ 3قسم الالبان - العركز القومى للبحوث - الدقى - جيزة - مصر.
}

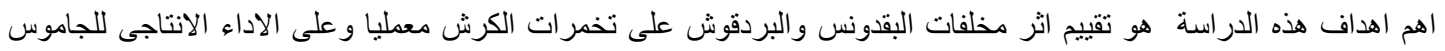

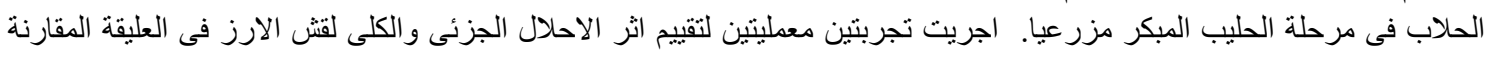

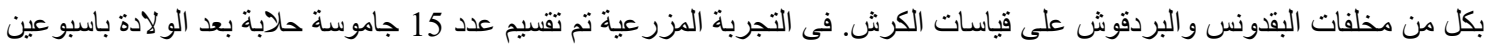

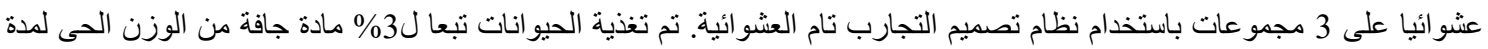

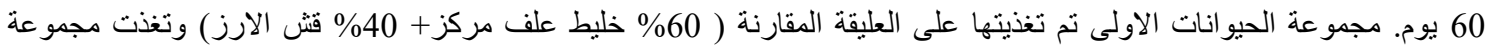

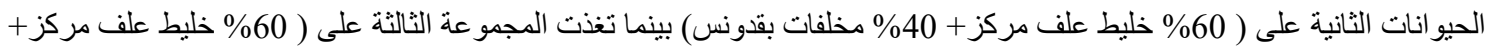

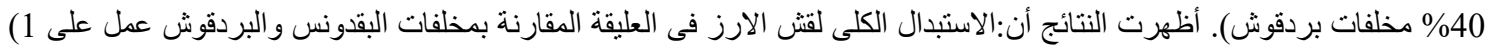

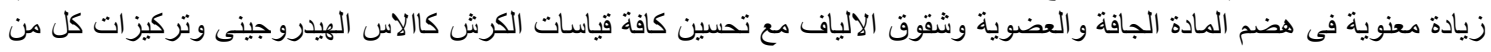

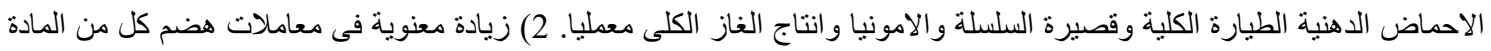

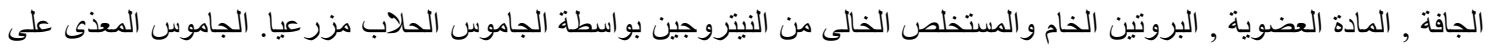

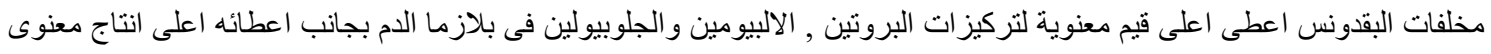

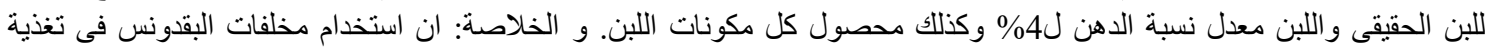

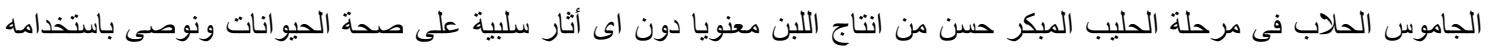

كمدر علف خشن خاصة فى الصيف. 